\title{
Comparison of Claw Health and Milk Yield in Dairy Cows on Elastic or Concrete Flooring
}

\author{
P. V. Kremer, ${ }^{\star 1}$ S. Nueske, ${ }^{\star}$ A. M. Scholz, ${ }^{\star}$ and M. Foerster ${ }^{\star} \dagger$ \\ *Livestock Center Oberschleissheim, and \\ †Institute of Animal Breeding, Veterinary Faculty, University of Munich, Germany
}

\begin{abstract}
This article reports on the effects of elastic (rubber) flooring compared with concrete flooring on claw health and milk yield in dairy cows. Milk yield and activity data of 53 complete lactations from 49 cows were recorded by an automatic milking system in the University of Munich Livestock Center dairy herd. Cows were kept in a loose housing system on concrete-slatted or rubber-matted slatted flooring. Claws were trimmed and measured linearly in combination with claw lesion diagnosis 3 times during one lactation period (including the transition phase). An automatic milking system recorded milk yield and activity. The net horn growth of the claws increased on elastic flooring. Therefore, correct and frequent claw trimming is at least as important for claw health in dairy herds kept on rubber flooring as for those on concrete-slatted flooring. Cows housed on rubber had an increased incidence of sole ulcers. Sole hemorrhages (except for hemorrhages associated with sole ulcers) occurred less frequently on rubber than on concrete. Results concerning digital dermatitis were difficult to assess, because manual manure scraping on rubber required sprinkling the flooring twice daily, which additionally moistened the digital skin of the cows. This might explain the greater incidence of digital dermatitis on elastic flooring. The incidence of clinically lame cows did not differ between flooring types. Cows showed greater activity on rubber, most likely caused by the more comfortable walking surface compared with the concrete-slatted flooring. The greater activity may indicate better overall health of high-yielding dairy cows on rubber flooring. Milk yield, however, did not differ between flooring types.
\end{abstract}

Key words: elastic flooring, claw health, lameness, milk yield

\footnotetext{
Received August 22, 2006.

Accepted June 20, 2007.

${ }^{1}$ Corresponding author: Prisca.Kremer@lvg.vetmed. uni-muenchen.de
}

\section{INTRODUCTION}

Lameness is an important economic and welfare issue in dairy cattle production, resulting in productive and financial losses (Enting et al., 1997; Green et al., 2002). Therefore, efforts to prevent claw lesions become even more important. The pathogenesis of claw diseases is multifactorial: management, nutrition, genetics, housing, and claw trimming are crucial factors, but the development of lameness is also directly linked to flooring conditions (Shearer and Van Amstel, 2000; Bergsten, 2004; Vanegas et al., 2006). Most dairy cattle facilities are equipped with hard, unyielding alleys that can have adverse effects on claw health (Russel et al., 1982; Frankena et al., 1991; Albright, 1995) including an increased incidence of claw lesions (Bergsten, 1994; Manske, 2002). Some concrete floorings are abrasive (Murphy and Hannan, 1987) and disturb the approximately equal rates of horn growth and wear that occur under natural conditions (Vermunt and Greenough, 1995); this disruption can eventually cause claw deformation (Hahn et al., 1986). Additionally, there is a 2-fold greater load and pressure during walking compared with standing. The greater load and pressure affects the susceptible structures of bovine claws (Scott, 1988; Van der Tol et al., 2003). Cattle husbandry in freestalls, however, forces cows to walk. To increase cow comfort and animal welfare, an elastic surface is more frequently considered for the walking alleys in freestalls of dairy cattle. Results of different studies have shown positive effects of rubber mats on claw health in tie-stall barns (Bergsten and Frank, 1996) and freestall barns (Benz, 2002; Vanegas et al., 2006). Benz (2002) examined the claw health of dairy cows kept in free-stall barns on concrete slatted flooring followed by housing on rubber-matted slatted flooring. Her results demonstrated decreasing severity of sole hemorrhages, sole ulcers, and white line lesions on elastic flooring. Histological examination of horn samples showed positive modifications of horn cell architecture on the elastic flooring. Vokey et al. (2003) reported that the greatest maintenance of balance between inner and outer claws occurred in dairy cows housed on soft walking alleys 
Table 1. Number of cows within genotype ${ }^{1}$ and lactation number on concrete and rubber flooring

\begin{tabular}{|c|c|c|c|c|c|c|}
\hline \multirow[b]{2}{*}{ Lactation } & \multicolumn{3}{|c|}{ Concrete-slatted flooring } & \multicolumn{3}{|c|}{ Rubber-matted slatted flooring } \\
\hline & GHFV & FVGH & Total & GHFV & FVGH & Total \\
\hline 1 & 10 & 6 & 16 & 9 & 5 & 14 \\
\hline 2 & 7 & 4 & 11 & 7 & 5 & 12 \\
\hline Total & 17 & 10 & 27 & 16 & 10 & 26 \\
\hline
\end{tabular}

combined with sand stalls. In an earlier study, however, Vokey et al. (2001) found no benefit of soft walking alleys for the prevention of claw lesions or clinical lameness. Other authors reported worsening of claw health in dairy cows (Samel, 2005) or in fattening bulls (Bahrs, 2005) kept on rubber slats compared with concrete slats.

This aim of this study was to compare claw health and milk yield of dairy cows kept on concrete or elastic flooring in a free-stall system during an entire lactation period.

\section{MATERIALS AND METHODS}

\section{Animal Characteristics and Treatment Assignments}

In total, $49 \mathrm{~F}_{1}$ crossbred dairy cows of German Holstein $(\mathbf{G H})$ and German Fleckvieh (FV) origin, from the 120-cow herd in the Livestock Center of the University of Munich, entered the study. The analysis included only first- and second-parity cows of both $\mathrm{F} 1$ genotypes: GHFV and FVGH (where the first part of the abbreviation represents the sire breed). The data originated from 53 lactation periods including 4 cows in their first and second lactations. All heifers grew up in a free-stall barn on concrete-slatted flooring.

A software program (Excel, 2003; Microsoft Corp., Redmond, WA) assigned the cows randomly into 1 of 2 groups (Table 1).

Both groups were kept in the same cubicle housing system divided by a feeding alley into 2 parallel units each containing 64 cubicles with identical dimensions. The experimental group was kept on rubber-matted slatted flooring (RMSF), where the originally concreteslatted flooring was covered with precisely cut rubber mats (KURA S, Kraiburg, Tittmoning, Germany). In this unit, stall bed surfaces were very comfortable rubber mattresses (type KKM, type KKE, or type KSL, Kraiburg), which were renewed 3 mo before installing the rubber flooring to avoid cows lying on the walking alleys. The control group stayed on conventional 17-yrold concrete-slatted flooring (CSF). In this unit, strawmanure mixture (with chaffed straw) renewed daily served as bedding material. The CSF unit was equipped with self-closing feeding head yokes for 54 cows. The RMSF unit had 28 single feeding troughs with an integrated weighing system. Forty-eight cows were kept per unit (CSF or RMSF) during time of data collection. Both groups were milked by using an automatic milking system (AMS, Astronaut, Lely, Maassluis, the Netherlands). After a necessary sprinkling of the rubber-covered flooring, staff in both units manually removed the manure in the alleys and RMSF cubicles twice a day. Cows received a TMR calculated for $700 \mathrm{~kg}$ of BW and a milk yield of $27 \mathrm{~kg} / \mathrm{d}$, containing $4.0 \%$ fat and $3.4 \%$ protein (Table 2 ). In addition, cows obtained the concentrate in the AMS, depending on the daily milk yield (DMY). Cows with a DMY of $15,20,25,30,35,40,45$, 50,55 , or $60 \mathrm{~kg}$ received $1,2,3,4,5,6,7,8,9$, or 10 $\mathrm{kg} / \mathrm{d}$ of concentrate, respectively. The amount of concentrate was adjusted weekly during the lactation.

\section{Study Design and Data Collection}

The study covered a whole lactation period per cow to ensure the same metabolic and physical stress for

Table 2. Composition of TMR and concentrate fed in the automatic milking systems (AMS)

\begin{tabular}{lc}
\hline Composition & \% of DM \\
\hline Ingredients & \\
Grass silage & 25.9 \\
Corn silage & 41.2 \\
Hay & 2.4 \\
Corn & 2.4 \\
Rapeseed meal & 4.9 \\
Soybean meal & 4.8 \\
Concentrate TMR & \\
Wheat & 1.7 \\
Barley & 1.2 \\
Oats & 0.8 \\
Corn & 1.0 \\
Mineral and vitamin mix & 0.1 \\
Concentrate AMS & 2.4 \\
Corn & 3.4 \\
Winter barley & 3.9 \\
Winter wheat & 3.4 \\
Soybean meal & 0.5 \\
Mineral and vitamin mix & \\
Nutrients & 15.8 \\
CP & 24.2 \\
Starch & 6.93 \\
NE L MJ/kg of DM &
\end{tabular}


all cows. Data collection started on d 21 before the expected day of calving (M1). Cows were restrained on a tilt table and linear measurements on all 8 claws were performed. A sliding caliper (Mitutoyo Messgeraete GmbH, Neuss, Germany) and a goniometer (Frei AG, Kirchzarten, Germany) served as a measuring tool for each claw. The following traits were determined: dorsal wall length (DWL), heel depth (HD), heel length (HL), wall diagonal (WD), sole length (SL), toe angle (TA), and heel angle (HA). The same person measured all traits per claw throughout the study. Before claw measurements, cows in late pregnancy received a uterine relaxant to avoid abortion. After the first measurement, all claws were trimmed according to the functional claw trimming method described by Toussaint Raven et al. (1985). After that trimming, claws were measured again. At the same time, later at 150 DIM (M2), and again at 305 DIM (M3), a veterinarian examined all claws for any kind of claw disease. Cows diagnosed as clinically lame received approved veterinary treatment, including functional claw trimming on the affected claw. Claws trimmed more frequently than M1, M2, or M3 were excluded from data collection at the following measurement. All claw lesions were recorded according to the relevant diagnosis. Digital dermatitis (DD) was identified independent of the number of lesions or dimension. Heel erosion (HE) described cleft heel-horn. The term sole ulcer (SU) was used for ulcers distal to the insertion of deep flexor tendon according to Rusterholz (1920). Hemorrhages distal to the insertion of deep flexor tendon (HDFT) were classified depending on the diagnosis of SU, by assuming that HDFT was an early stage of SU. Hemorrhages at the white line and in the sole-horn, with exception of HDFT, were identified as sole hemorrhages (SH). White line disease (WLD) is an infection of the corium starting from the abaxial, proximal part of the white line (zone 3, according to Leach et al., 1998). Hyperplasia interdigitalis (HI) was recognized independent of its dimension. Cows affected by laminitis were defined as cows not affected by any claw diseases but clinically lame and pressure-sensitive on all claws. Cows were diagnosed as having phlegmona interdigitalis when symptoms of limb swelling, body temperature $>39.5^{\circ} \mathrm{C}$, abnormal general condition, and no further visible leg injury except interdigital dermatitis were present.

All cows received neck collars for identification including an activity counter (Nedap-agri AM-activitycollar, Groenlo, the Netherlands), which increased by 1 unit for every 40 movements of the neck. The AMS recorded activity data and milk yield at every visit of every cow.

\section{Statistical Analyses}

The SAS software package (version 8.2; SAS Institute Inc., Cary, NC) provided the tools for data analysis using a GLM with the following structure for linear claw traits:

$$
\mathrm{y}_{\mathrm{ijkl}}=\mu+\mathrm{G}_{\mathrm{i}}+\mathrm{H}_{\mathrm{j}}+\mathrm{G}_{\mathrm{i}} \times \mathrm{H}_{\mathrm{j}}+\mathrm{C}_{\mathrm{k}}+\mathrm{e}_{\mathrm{ijkl}}
$$

where $y_{i j k l}=$ observation, $\mu=$ expected value of $y, G_{i}=$ genotype $(i=1,2), H_{j}=$ housing $(j=1,2), G_{i} \times H_{j}=$ interaction $\mathrm{G} \times \mathrm{H}(\mathrm{i} \times \mathrm{j}), \mathrm{C}_{\mathrm{k}}=$ claw $(\mathrm{k}=1,2,3,4,5,6$, $7,8)$, and $\mathrm{e}_{\mathrm{ijkl}}=$ residual error.

The following model served for the analysis of milk yield:

$$
\mathrm{y}_{\mathrm{ijklm}}=\mu+\mathrm{G}_{\mathrm{i}}+\mathrm{H}_{\mathrm{j}}+\mathrm{G}_{\mathrm{i}} \times \mathrm{H}_{\mathrm{j}}+\mathrm{H}_{\mathrm{j}} \times \mathrm{L}_{\mathrm{k}}+\mathrm{F}_{1}+\mathrm{e}_{\mathrm{ijklm}}
$$

where $\mathrm{y}_{\mathrm{ijk} k \mathrm{~m}}=$ observation, $\mu=$ expected value of $\mathrm{y}, \mathrm{G}_{\mathrm{i}}=$ genotype $(i=1,2), H_{j}=$ housing $(j=1,2), G_{i} \times H_{j}=$ interaction $\mathrm{G} \times \mathrm{H}(\mathrm{i} \times \mathrm{j}), \mathrm{H}_{\mathrm{j}} \times \mathrm{L}_{\mathrm{k}}=$ interaction of housing $\times$ day of lactation $(\mathrm{k}=1,2, \ldots, 301)(\mathrm{j} \times \mathrm{k}), \mathrm{F}_{1}=$ concentrate $(1=1,2,3,4,5,6,7,8,9,10)$, and $\mathrm{e}_{\mathrm{ijk} \mathrm{km}}=$ residual error.

Activity data were logarithmized (ln) to get a normal distribution of data and analyzed by using the following model:

$$
\begin{gathered}
\mathrm{y}_{\mathrm{ijklmno}=\mu}+\mathrm{G}_{\mathrm{i}}+\mathrm{H}_{\mathrm{j}}+\mathrm{G}_{\mathrm{i}} \times \mathrm{H}_{\mathrm{j}}+\mathrm{F}_{\mathrm{k}}+\mathrm{L}_{\mathrm{l}} \\
+\mathrm{J}_{\mathrm{m}} \times \mathrm{Q}_{\mathrm{n}}+\mathrm{e}_{\mathrm{ijklmno}}
\end{gathered}
$$

where $\mathrm{y}_{\mathrm{ijklmno}}=$ observation, $\mu=$ expected value of $\mathrm{y}$, $\mathrm{G}_{\mathrm{i}}=$ genotype $(\mathrm{i}=1,2), \mathrm{H}_{\mathrm{j}}=$ housing $(\mathrm{j}=1,2), \mathrm{G}_{\mathrm{i}} \times \mathrm{H}_{\mathrm{j}}=$ interaction $\mathrm{G} \times \mathrm{H}(\mathrm{i} \times \mathrm{j}), \mathrm{F}_{\mathrm{k}}=$ concentrate classes $(\mathrm{k}=$ $1,2,3,4,5,6,7), \mathrm{L}_{\mathrm{l}}=$ number of lactation $(\mathrm{l}=1,2), \mathrm{J}_{\mathrm{m}}$ $\times Q_{n}=$ interaction of year $(m=1,2) \times$ quarter $(n=1$, $2,3,4)$, and $\mathrm{e}_{\mathrm{ijk} k \mathrm{mno}}=$ residual error.

Activity data analysis included effects of year and season covering the time between November 2002 and March 2005. Because only 1 cow in 2002 and 3 cows in 2005 entered the study, the records of these 4 cows formed joint classes with the following or previous quarter, respectively. Finally, the model contained 8 yr-season classes ( $2 \mathrm{yr} \times 4$ quarters). Furthermore, the individual cow records formed 7 concentrate classes depending on the concentrate amount in the AMS. Concentrate classes including only a small number of cows were merged with the next higher or lower class. The first concentrate class included all cows receiving $<3 \mathrm{~kg}$ concentrate/d and the seventh class included cows receiving $\geq 8 \mathrm{~kg}$ concentrate/d. A simple percentage evaluation was performed for the analysis of the incidence of all detected claw diseases. 


\section{RESULTS}

The least squares means (LSM) for measurements of claw dimensions are shown in Tables 3 and 4. Table 3 represents the LSM of the first trial period (M1 to M2), and Table 4 represents the LSM of the second trial period (M2 to M3). To provide a better overview, the LSM of the differences between the 2 successive clawtrait measurements appear in the corresponding table.

Data of both trial periods showed significant differences in the development of claw shape depending on floor conditions. The first trial period showed differences in DWL and WD $(P<0.001)$. Claws of the RMSF group had higher values for both traits compared with claws of the CSF group. The longer claw shape resulted in a steeper TA $(P=0.001)$ and an increasing HA $(P<$ $0.001)$. Sole length tended to be longer in claws of the RMSF group than in the CSF group $(P=0.055)$. Heel length $(P=0.124)$ and $\mathrm{HD}(P=0.564)$ displayed no differences in the first trial period. Data of the second trial period showed significant differences for all measured claw traits. Dorsal wall length $(P<0.001)$, WD $(P=0.013)$, and SL $(P<0.001)$ were greater in claws of the RMSF group. In addition, HL and HD increased in the RMSF group $(P<0.001)$. In accordance with the claw shape development of the first trial period, TA in claws of the RMSF group decreased $(P=0.02)$ and HA in claws of the RMSF group increased $(P<0.001)$ in the second trial period.

Refer to Figure 1 for a summary of claw evaluations. This figure represents only diagnostic results at the time of measurements M1, M2, and M3. Therefore, no clinical lameness is included. All diseases diagnosed showed a similar distribution of affected cows between both groups at the beginning of the study (M1), with exception of DD and HE. Digital dermatitis (14\% CSF vs. $23 \%$ RMSF) was more common in the RMSF group and HE was more common in the CSF group (25 vs. $7 \%$ ). At the time of M2, DD (18 vs. $42 \%$ ), HE (25 vs. $53 \%$ ), SU (11 vs. $23 \%$ ), and HDFT (18 vs. $30 \%$ ) were more common in the RMSF group than in the CSF group. Only SH was observed more often (37 vs. 30\%) in claws of animals in the CSF group. At the time of M3, DD was still more common in the RMSF group (29 vs. $53 \%$ ), and the incidence of $\mathrm{HE}$ was greater in the CSF group (62 vs. 46\%). The remaining diseases showed only slight or no differences in incidence at the time of M3. Incidence of HI seemed to be unaffected by flooring, with no affected cows at M2 and 7\% of cows affected in both groups at M3. In addition to these results, Figure 2 represents the percentage of lame cows during the study. Clinical lameness occurred in $22 \%$ of the CSF cows and was caused by SU ( 2 cows), laminitis (1 cow), HI (1 cow), WLD (1 cow), and phlegmona interdigitalis

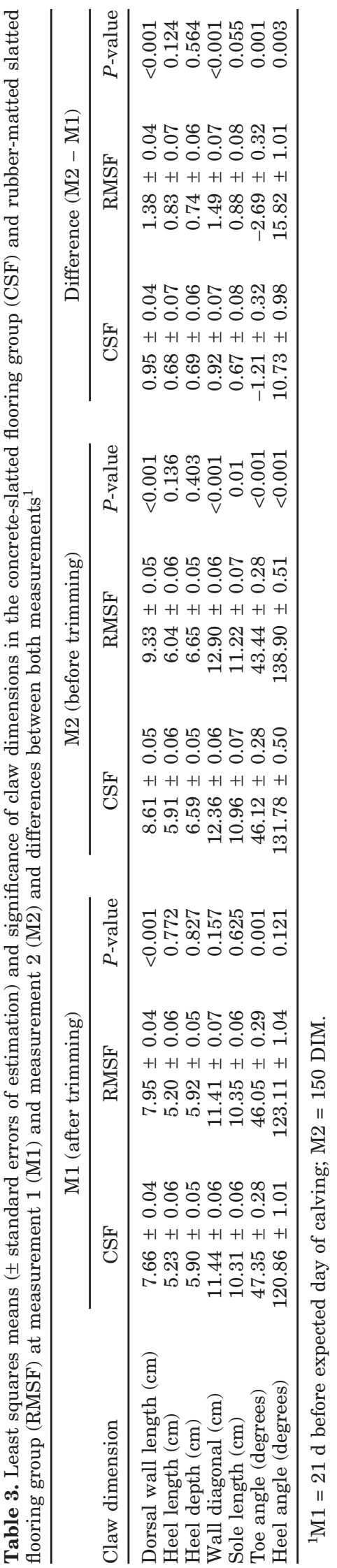


(1 cow). In total, $26 \%$ of the RMSF cows showed signs of clinical lameness, caused by SU (1 cow), laminitis ( 2 cows), HI (1 cow), and WLD (3 cows).

The groups did not significantly differ in mean DMY (24.59 vs. $24.51 \mathrm{~kg}$ for $\mathrm{CSF}$ and RMSF, respectively; $P=0.489$; Figures 3 and 4). Additionally, flooring condition did not affect the pattern of mean DMY over 305 d (Figure 4). Figure 5 compares the mean daily activity between the 2 groups. The RMSF group showed greater $(P<0.001)$ mean daily activity level than did the CSF group.

\section{DISCUSSION}

Age, calving, genetics, and metabolic stress of lactation stage are all factors that influence claw health and milk yield, so only cows of similar age and genetics were selected for this trial. To ensure the same metabolic and physical stress for all cows, we collected data over a complete lactation period, starting $21 \mathrm{~d}$ before the expected day of calving and ending at 305 DIM. During the experiment, the claws of both groups were trimmed every $6 \mathrm{mo}$, representing the typical on-farm interval for claw trimming. Nevertheless, measurements of the claw traits showed significant differences in claw development between both groups. Claw shape of the RMSF group differed significantly from claw shape of the CSF group in both trial periods. These results confirm previous studies regarding deformations of the horn capsule due to less wear in claws of dairy cows kept on rubbermatted slatted flooring (Kremer et al., 2004) or in cows kept on straw yards compared with concrete flooring (Somers et al., 2005). Samel (2005) detected greater net horn growth followed by horn capsule deformation on elastic flooring compared with concrete flooring in cows adapted to rubber flooring, and thus ruled out further adaptation of horn growth to reduced wear. These results, however, are contrary to results of Jungbluth et al. (2003), who reported no difference in horn wear between animals housed on rubber and concrete flooring. A known consequence of a claw shape that is too long is a change in the functional angulations of the bovine claw. In a functional trimmed claw, as defined by Toussaint Raven et al. (1985), the mean center of load of BW is shifted toward the tip of the limb with a maximum of $8 \mathrm{~mm}$ and $25 \mathrm{~mm}$ toward the region of the interdigital space (Kehler and Gerwing, 2004). When the claw is too long, the angles change, as shown in our results, displacing the center of the load to the bulb (Toussaint Raven et al., 1985). In the RMSF group, TA became significantly greater (i.e., steeper) and HA significantly greater than in the CSF group in both trial periods. This might influence the onset of SU and HDFT (Toussaint Raven et al., 1985). Consequently, we de- 


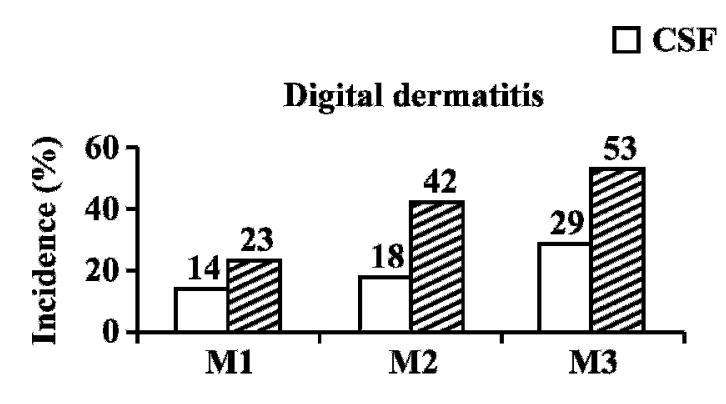

\section{$\square$ RMSF}
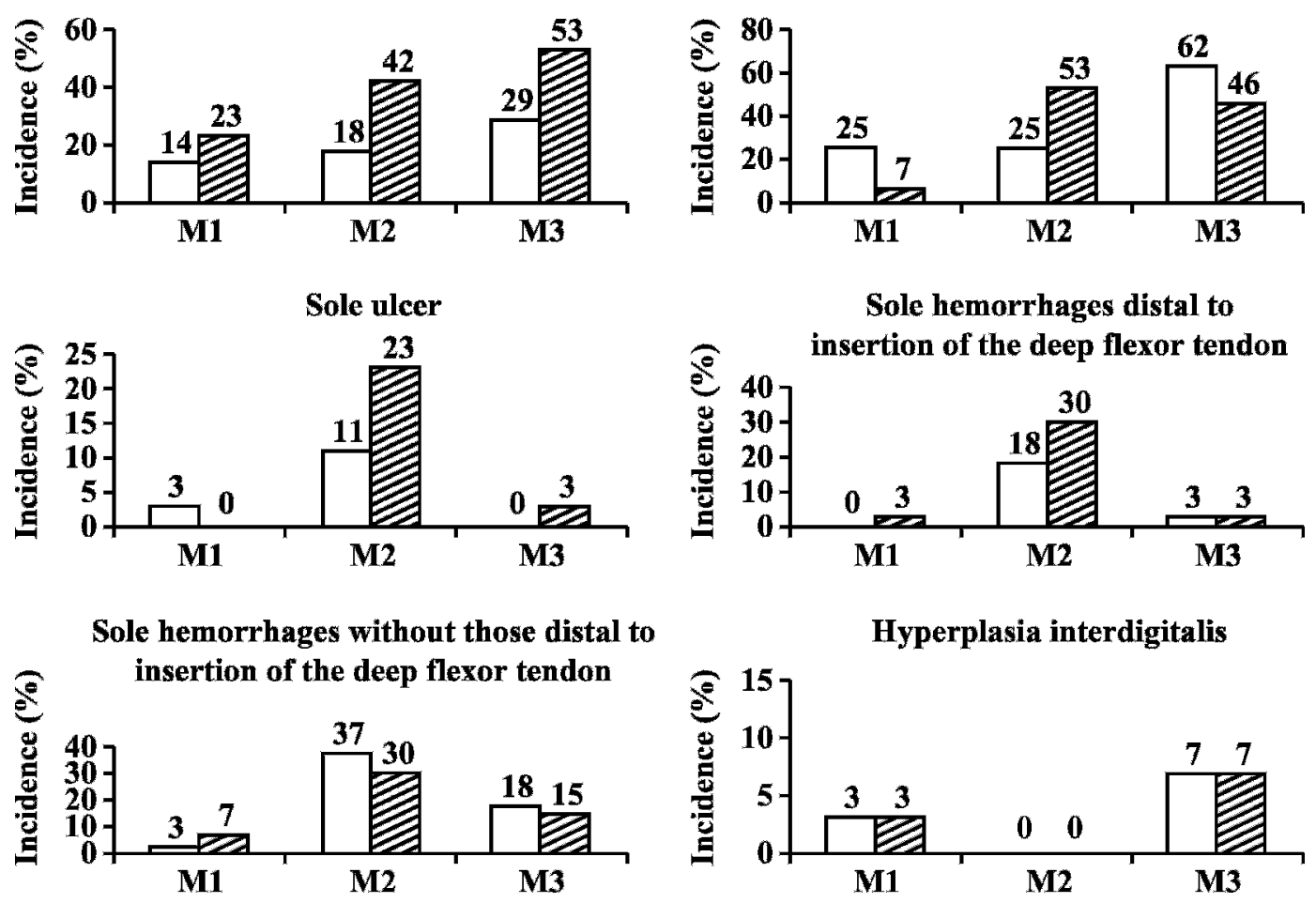

Figure 1. Incidence (\%) of different claw diseases without clinical lameness at the time of trial start (M1), 150 DIM (M2), and 305 DIM (M3) comparing concrete-slatted flooring (CSF) with rubber-matted slatted flooring (RMSF).

tected, in the first trial period, a greater incidence of $\mathrm{SU}$ and HDFT in the RMSF group than in the CSF group. In the CSF group, the greatest incidence of SU and HDFT occurred at M2, but at a lower level than in the RMSF group. This result agrees with those of Manske (2002), who showed that the highest risk for onset of SU and HDFT in dairy cattle occurred between 61 and 150 DIM. Our results confirm an additional

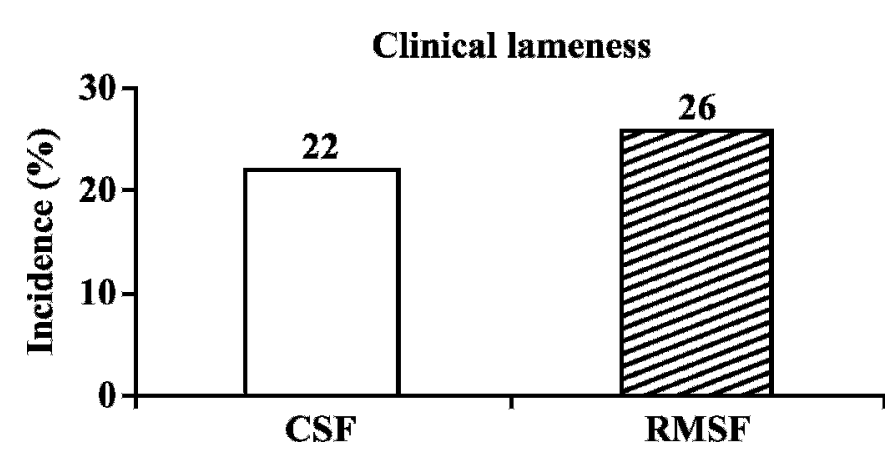

Figure 2. Incidence $(\%)$ of clinical lameness comparing concreteslatted flooring (CSF) with rubber-matted slatted flooring (RMSF) during the experimental period. negative effect of rubber slats on the incidence of SU and HDFT in the period of greatest risk during lactation. Within the second trial period, we found a significant enlargement of the heel in the RMSF group, in addition to the longer claw shape. Heel enlargement is likely a result of horn growth adaptation to flooring conditions, compensating for changes in the load exposure. That may explain why SU and HDFT occur spo-

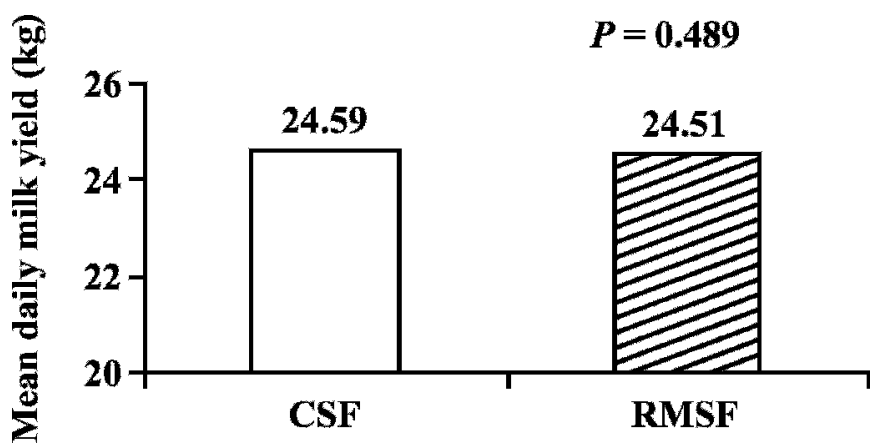

Figure 3. Mean daily milk yield of the concrete-slatted flooring group (CSF) and rubber-matted slatted flooring group (RMSF) during the experimental period. 


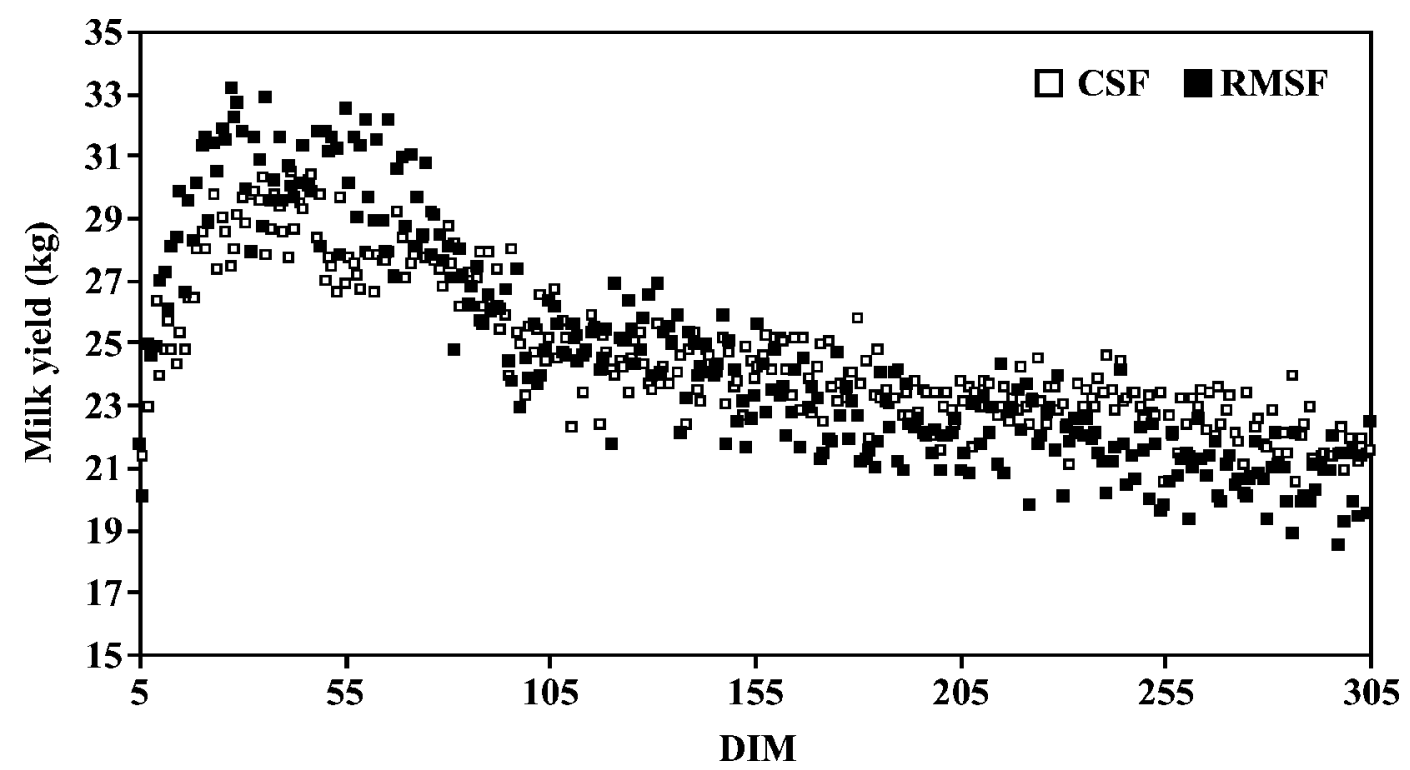

Figure 4. Change in mean daily milk yield between 5 and 305 DIM of the concrete-slatted flooring group (CSF) and rubber-matted slatted flooring group (RMSF).

radically during the second trial period, despite the significantly longer claw shape observed in these animals.

Digital dermatitis and $\mathrm{HE}$ are common diseases in animals housed in free-stalls. Therefore, there was a high incidence of both diseases at M1 in both groups. Incidence of DD, however, showed a more drastic increase in the RMSF group. In addition, the incidence of HE indicated that there was no benefit for claw health on rubber slats vs. concrete slats. Environmental effects such as hygiene and humidity influence the onset of both diseases. In this context, our results need a critical interpretation, and attention should be paid to the circumstances of manure scraping on the rubber slats. The rubber flooring required flushing with water twice daily, causing additional moistening of the digital skin.

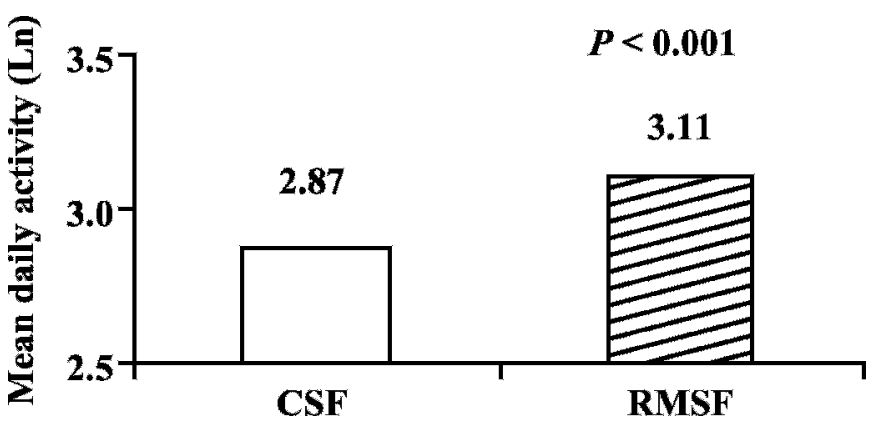

Figure 5. Mean daily activity (ln) of the concrete-slatted flooring group (CSF) and rubber-matted slatted flooring group (RMSF) during the experimental period.
Nevertheless, the results are similar to those of Bahrs (2005), who reported a greater incidence of DD in fattening bulls housed on rubber vs. concrete slats. Samel (2005) showed a greater incidence of HE in dairy cows housed on rubber slats compared with concrete slats. Therefore, an explanation for the development of DD and $\mathrm{HE}$ on rubber slats may be given by the significantly greater activity of the RMSF group. Digital dermatitis and HE are contagious and are more common in free-stall systems than in tie-stall systems (Manske, 2002). Thus, walking in free-stall systems seems to increase the risk of becoming infected. Consequently, the incidence of DD increases on concrete flooring, too. Evaluation of the activity data showed significantly greater activity in animals of the RMSF group. That finding corresponds with the results of Fregonesi et al. (2004), who demonstrated that cows spent more time standing, at the expense of lying, when they had access to rubber flooring. Therefore, the greater activity of the RMSF group affected the incidence of DD and HE because of the increased time spent in the alleys.

Another disease of major concern in dairy herds is laminitis. Although unbalanced nutrition is a causative factor in laminitis, some studies have described flooring as a factor influencing the rate and development of SH associated with laminitis (Bergsten and Frank, 1996). Hence, claw diagnosis for SH was important for our study. Our results showed slightly fewer cases of $\mathrm{SH}$ in the RMSF group than in the CSF group at M2 and M3. At M1, however, the RMSF group included more cows affected with SH than did the CSF group. Conse- 
quently, and in agreement with Benz (2002), rubber slats seem to reduce SH caused by trauma compared with a hard and unyielding slatted floor. The incidence of HI was completely unaffected by flooring condition during this experiment. Contrary to the results of Samel (2005), who reported an approximately $50 \%$ greater incidence of HI on rubber-slatted flooring compared with concrete-slatted flooring, we found the same number of cows affected with $\mathrm{HI}$ at all claw evaluations. Besides cows with claw diseases that did not involve lameness recorded during the functional trimming at M1, M2, and M3, we identified clinically lame cows. In agreement with Vokey et al. (2001), we did not find a considerable difference in the incidence of clinical lameness between the groups housed on rubber or concrete flooring. This result confirms that the functional claw trimming method is suitable for animals housed on concrete as well as rubber flooring.

Because of the high economic pressure challenging the dairy industry, the financial return of investments in housing equipment is of major concern. Therefore, we evaluated the DMY of cows in the 2 groups. Friend et al. (1977) demonstrated that a 1:1 cow:feeding place ratio is not required if a TMR is available throughout the day. Thus, we disregarded the different proportion of feeding space and cows in the 2 groups. As in a previous study based on monthly performance test results (Kremer et al., 2006), we could not detect any difference in the mean DMY between dairy cows on rubber or concrete slats, nor any differences in changes in the mean DMY over $305 \mathrm{~d}$. The higher activity level in the RMSF group, however, seemed to indicate better walking comfort on elastic flooring.

\section{CONCLUSIONS}

Elastic flooring in free-stall systems reduces horn wear. Consequently, claw shape differs from that of cows kept on concrete flooring. We conclude that claw shape differing from a functional one requires a correct claw trimming to be performed. Hence, claw trimming is even more important for cows kept on elastic flooring than for cows kept on concrete flooring. The claw-trimming interval of 6 mo was adequate. A longer clawtrimming interval seems inappropriate, especially concerning the high incidence of sole ulcers and associated hemorrhages in the cows housed on the elastic flooring. Based on the claw-trimming interval of $6 \mathrm{mo}$, we do not expect that the rate of clinical lameness in dairy herds would increase because of less wear from rubber mats. Our results, however, showed that elastic flooring (rubber mats) does not necessarily improve claw health with respect to the disorders evaluated in this study. Greater activity, however, in cows housed on elastic flooring indicated increased comfort during the time spent moving. During the course of one lactation period, a greater level of walking comfort by elastic flooring did not lead to significantly greater milk yield. Currently, studies about elastic flooring continue to evaluate its advantages and disadvantages. Ongoing long-term studies might show evidence for greater overall health and longevity of dairy cows kept on elastic flooring because of improved cow comfort.

\section{ACKNOWLEDGMENTS}

We thank the Gummiwerk Kraiburg (Tittmoning, Germany) and especially Barbara Benz for equipping stalls and alleys of one dairy unit of the Livestock Center Oberschleissheim with the appropriate rubber mats.

\section{REFERENCES}

Albright, J. C. 1995. Flooring in dairy cattle facilities. Pages 168-182 in Proc. Int. Conf. Anim. Behav. Design Livest. Poult. Systems, Indianapolis, IN.

Bahrs, E. 2005. Verhalten und Gesundheitsstatus von Mastbullen auf Gummispaltenboden. PhD Thesis. Ludwig Maximilians Univ., München, Germany.

Benz, B. 2002. Elastische Beläge für Betonspaltenböden in Liegeboxenlaufställen. $\mathrm{PhD}$ Thesis. Univ. Hohenheim, Stuttgart, Germany.

Bergsten, C. 1994. Haemorrhages of the sole-horn of dairy cows as a retroperspective indicator of laminitis: An epidemiological study. Acta Vet. Scand. 35:55-66.

Bergsten, C. 2004. Healthy feet requires cow comfort 24 hours. Pages 186-191 in Proc. 13th Int. Symp. Lameness in Ruminants, Maribor, Slovenia. B. Zemljic, Maribor, Slovenia.

Bergsten, C., and B. Frank. 1996. Sole haemorrhages in tied primiparous cows as an indicator of periparturient laminitis: Effects of diet, flooring and season. Acta Vet. Scand. 37:383-394.

Enting, H., D. Kooij, A. A. Dijkhuizen, R. B. M. Huirne, and E. N. Noordhuizen-Stassen. 1997. Economic losses due to clinical lameness in dairy cattle. Livest. Prod. Sci. 49:259-267.

Frankena, K., E. N. Stassen, J. P. Noordhuizen, J. O. Goelema, J. Schipper, H. Smelt, and H. Romkema. 1991. Prevalence of lameness and risk indicators for dermatitis digitalis during pasturing and housing of dairy cattle. Pages 107-118 in Proc. Ann. Symp. Soc. Vet. Epidemiol. Prev. Med., London, UK. G. J. Rowlands, London, UK.

Fregonesi, J. A., C. B. Tucker, D. M. Weary, F. C. Flower, and T. Vittie. 2004. Effect of rubber flooring in front of the feed bunk on the time budgets of dairy cattle. J. Dairy Sci. 87:1203-1207.

Friend, T. H., C. E. Polan, and M. L. McGilliard. 1977. Free stall and feed bunk requirements relative to behavior, production and individual feed intake in dairy cows. J. Dairy Sci. 60:108-116.

Green, L. E., V. J. Hedges, Y. H. Schukken, R. W. Blowey, and A. J. Packington. 2002. The impact of clinical lameness on the milk yield of dairy cows. J. Dairy Sci. 85:2250-2256.

Hahn, M. V., B. T. McDaniel, and J. C. Wilk. 1986. Rates of hoof growth and wear in Holstein cattle. J. Dairy Sci. 69:2148-2156.

Jungbluth, T., B. Benz, and H. Wandel. 2003. Soft walking areas in loose housing systems for dairy cows. Pages 171-177 in Proc. Dairy Housing Conf., Fort Worth, TX. Am. Soc. Agric. Eng., St. Joseph, MI.

Kehler, W., and T. Gerwing. 2004. Effects of functional claw trimming on pressure distribution under hind claws of German Holstein cows. Pages 103-104 in Proc. 13th Int. Symp. Lameness in Ruminants, Maribor, Slovenia. B. Zemljic, Maribor, Slovenia. 
Kremer, P., S. Nueske, A. M. Scholz, and M. Foerster. 2004. Influence of different floor conditions on claw development, metabolism and milk yield in dairy cows housed in stalls with free cow traffic. Pages 210-212 in Proc. 13th Int. Symp. Lameness in Ruminants, Maribor, Slovenia. B. Zemljic, Maribor, Slovenia.

Kremer, P., S. Nueske, A. M. Scholz, and M. Foerster. 2006. Effect of soft flooring in free stalls on milk yield, fat, protein and somatic cell counts in dairy cattle. Arch. Tierzucht. 49:250-258.

Leach, K. A., D. N. Logue, J. M. Randall, and S. A. Kempson. 1998. Claw lesions in dairy cattle: Methods for assessment of sole and white line lesions. Vet. J. 155:91-102.

Manske, T. 2002. Hoof lesions and lameness in Swedish dairy cattle; prevalence, risk factors, effects of claw trimming and consequences of productivity. PhD Thesis. Swedish Univ. Agric., Skara.

Murphy, P. A., and J. Hannan. 1987. Effects of slatted flooring on claw shape in intensively housed fattening beef cattle. Bovine Pract. 22:133-135.

Russel, A. M., G. J. Rowlands, S. R. Shaw, and A. D. Weaver. 1982. Survey of lameness in British dairy cattle. Vet. Rec. 111:155-160.

Rusterholz, A. 1920. Das spezifisch-traumatische Klauensohlengeschwür des Rindes. Schweiz. Arch. Tierheilk. 62:421-466.

Samel, M. 2005. Gummibeschichtete Laufflächen für Milchkühe und deren Einfluss auf Klauenwachstumsparameter und Klauengesundheit im Vergleich zu betonierten Laufflächen. PhD Thesis. Tierarztl. Hochschule, Hannover, Germany.

Scott, G. B. 1988. Studies of the gait of Friesian heifer cattle. Vet. Rec. 123:245-248.
Shearer, J. K., and S. Van Amstel. 2000. Lameness in dairy cattle. Pages 1-12 in Proc. Kentucky Dairy Conf. http://www.uky.edu/ Ag/AnimalSciences/dairy/dairyconference/dairyconference. html Accessed Aug. 20, 2007.

Somers, J. G. C. J., W. G. P. Schouten, K. Frankena, E. N. Noordhuizen-Stassen, and J. H. M. Metz. 2005. Development of claw traits and claw lesions in dairy cows kept on different floor systems. J. Dairy Sci. 88:110-120.

Toussaint Raven, E., R. T. Halstra, and D. J. Peterse. 1985. Cattle foot care and claw trimming. Farming Press, Ipswich, UK.

Van der Tol, P. P. J., J. H. M. Metz, E. N. Noordhuizen-Stassen, W. Back, C. R. Braam, and W. A. Weijs. 2003. The vertical ground reaction force and the distribution on the claws of dairy cows while walking on a flat substrate. J. Dairy Sci. 86:2875-2883.

Vanegas, J., M. Overton, S. L. Berry, and W. M. Sischo. 2006. Effect of rubber flooring on claw health in lactating dairy cows housed in free-stall barns. J. Dairy Sci. 89:4251-4258.

Vermunt, J. J., and P. R. Greenough. 1995. Structural characteristics of the bovine claw horn growth and wear, horn hardness and claw conformation. Br. Vet. J. 151:157-180.

Vokey, F. C., C. L. Guard, H. N. Erb, and D. M. Galton. 2001. Effects of alley and stall surfaces on indices of claw and leg health in dairy cattle housed in a freestall barn. J. Dairy Sci. 84:2686-2699.

Vokey, F. C., C. L. Guard, H. N. Erb, and D. M. Galton. 2003. Observation on flooring and stall surfaces for dairy cattle housed in a freestall barn. Pages 165-170 in Proc. Dairy Housing Conf., Fort Worth, TX. Am. Soc. Agric. Eng., St. Joseph, MI. 